\title{
Choline Modulation of the A $\beta$ P1-40 Channel Reconstituted into a Model Lipid Membrane
}

\author{
Daniela Meleleo, Gabriella Notarachille, and Silvia Micelli \\ Dipartimento Farmaco-Biologico, Università degli Studi di Bari, Via E. Orabona 4, 70126 Bari, Italy \\ Correspondence should be addressed to Silvia Micelli, micelli@farmbiol.uniba.it
}

Received 26 July 2010; Accepted 10 November 2010

Academic Editor: Hyoung-gon Lee

Copyright ( $) 2010$ Daniela Meleleo et al. This is an open access article distributed under the Creative Commons Attribution License, which permits unrestricted use, distribution, and reproduction in any medium, provided the original work is properly cited.

\begin{abstract}
Nicotinic acetylcholine receptors (AChRs), implicated in memory and learning, in subjects affected by Alzheimer's disease result altered. Stimulation of $\alpha 7$-nAChRs inhibits amyloid plaques and increases ACh release. $\beta$-amyloid peptide $(\mathrm{A} \beta \mathrm{P})$ forms ion channels in the cell and model phospholipid membranes that are retained responsible in Alzheimer disease. We tested if choline, precursor of ACh, could affect the A $\beta$ P1-40 channels in oxidized cholesterol (OxCh) and in palmitoyl-oleoyl-phosphatidylcholine (POPC):Ch lipid bilayers. Choline concentrations of $5 \times 10^{-11} \mathrm{M}-1.5 \times 10^{-8} \mathrm{M}$ added to the cis- or trans-side of membrane quickly increased $\mathrm{A} \beta \mathrm{P} 1-40$ ion channel frequency (events $/ \mathrm{min}$ ) and ion conductance in OxCh membranes, but not in POPC:Ch membranes. Circular Dichroism (CD) spectroscopy shows that after 24 and 48 hours of incubation with A $\beta$ P $1-40$, choline stabilizes the random coil conformation of the peptide, making it less prone to fibrillate. These actions seem to be specific in that ACh is ineffective either in solution or on $\mathrm{A} \beta \mathrm{P} 1-40$ channel incorporated into PLMs.
\end{abstract}

\section{Introduction}

Alzheimer's disease (AD) is an age-related neurodegenerative disorder that is characterized by a progressive loss of memory and deterioration of higher cognitive functions. The wealth of evidence of early and major synaptic damage and loss [ 1 , 2 ], correlated with the severity of dementia [3-5], considers $\mathrm{AD}$ to be a disorder of synaptic function $[6,7]$.

Cholinergic neurons show particular vulnerability in the ageing process, which causes chronic deterioration of the brain component. It is a widespread belief among researchers that $\mathrm{A} \beta \mathrm{P}$ peptides are involved in the loss of cholinergic neurons from the basal forebrain area in $\mathrm{AD}$. Moreover, the mechanisms by which $\mathrm{A} \beta \mathrm{P}$ peptides influence/cause degeneration of basal forebrain cholinergic neurons and/or the cognitive impairment characteristic of $\mathrm{AD}$ remain obscure, although there is little doubt that early synaptic pathology precedes the clinical symptoms of $\mathrm{AD}[8,9]$.

Several hypotheses have been formulated to explain the onset of this disease such as: alterations in choline uptake, choline transport, impaired acetylcholine release, deficits in expression of nicotinic, and muscarinic receptors and channel formation by $\mathrm{A} \beta \mathrm{P}$ oligomers. An increase in choline flux across the membranes of neuronal cells exposed to $A \beta P$ has also been hypothesized to contribute to the selective vulnerability of cholinergic neurons in $\mathrm{AD}[10]$.

$\mathrm{A} \beta \mathrm{P}$ is an amphiphilic peptide with a hydrophilic Nterminal domain (residues 1-28) and a hydrophobic Cterminal (residues 29-40 (-42)), the latter corresponding to a part of the transmembrane domain of APP. CD studies have shown that $\mathrm{A} \beta \mathrm{P}$ changes its conformation from lipid-free $\mathrm{A} \beta \mathrm{P}$ in order to bind to phospholipid vesicles. A $\beta$ P consists of $48.9 \%$ random-coil, $23.5 \% \beta$-sheet, and $1.7 \%$ alpha-helix; while when reconstituted in phospholipid vesicles made up of 1,2-dimyristoyl-sn-glycero-3phosphocholine, both $\beta$-sheet and $\alpha$-helix contents increase by about $7 \%$, that is, the $\beta$-sheet increased to $31.2 \%$ and the $\alpha$-helix to $9.5 \%$, respectively [11]. It has been demonstrated that $\mathrm{A} \beta \mathrm{P}$ forms ion channels in the cell and model phospholipid membranes [12-14]; a $P_{K}{ }^{+} / P_{\mathrm{Cl}}{ }^{-}$ permeability ratio of 11 , with calcium permeability blocked by tromethamine and aluminium, has been reported [12]. Moreover, $\mathrm{A} \beta \mathrm{P}$ disrupted calcium homeostasis and increased calcium intracellular concentrations; these events may be 
responsible for cellular toxicity [15]. Recent studies indicate that the peptide's ability to form ion channels depends on its conformational structure and on the peptide/lipid structure in the physiological environment. Some authors have found that membrane components, such as cholesterol (Ch) and gangliosides, alter the affinity of $\mathrm{A} \beta \mathrm{P}$ for phospholipid membranes. In fact, $\mathrm{Ch}$ and gangliosides, once associated with phospholipid membranes, lead to an increase in $\beta$ sheet content and/or the rate of aggregation of $\mathrm{A} \beta \mathrm{P}$ [16]. On the other hand, other authors have shown that, when $\mathrm{A} \beta \mathrm{P}$ was added to a $33 \% \mathrm{Ch}$-containing 1,2-dimyristoyl-snglycero-3-phosphocholine vesicle, the structure of $\mathrm{A} \beta \mathrm{P}$ was drastically altered, that is, the $\beta$-sheet structure decreased to zero while the $\alpha$-helix increased to $58.8 \%$ [11]. In addition, alterations to the soluble $\mathrm{Ch}$ concentration and/or in $\mathrm{Ch}$ biosynthesis have been shown to affect the normal processing of APP, both in vivo and in vitro [17]. In a previous study, we investigated the role played by membrane composition on the interaction and self-assembly of $\mathrm{A} \beta \mathrm{P} 1-40$ during pore formation in PLMs. This study showed that A $\beta \mathrm{P} 1-40$ has a higher propensity to form channels in OxCh PLM (as compared to other neutral phospholipid PLMs, whether they contain sterols or not), where the channels present high conductance, high frequency, anion selectivity, and long lifetime [14].

In this study, we investigated the effects of choline on the A $\beta P 1-40$ ion channel in lipid bilayer membranes made up of $\mathrm{OxCh}$ and of POPC:Ch bilayer. OxCh membranes were used due to the evidence of a Ch-rich domain both in eukaryotic plasma membranes - such as brain and blood vessels_-and in aged membrane plaque. Besides, A $\beta$ P1-40 shows a higher affinity to $\mathrm{Ch}$ and its oxidation products than to phospholipids [14].

\section{Materials and Methods}

2.1. Single Channel Measurement. Channel activities were recorded in a lipid bilayer membrane made up of $\mathrm{OxCh}$ in n-decane (1:1, v:v) (Fluka) or POPC:Ch $(65: 35, \mathrm{w} / \mathrm{w})$ in $1 \% \mathrm{n}$-decane. OxCh was obtained following the method of Tien et al. [18]. Bilayers were formed across a $300 \mu \mathrm{m}$ hole in a Teflon partition separating two Teflon chambers (volume $4000 \mu \mathrm{l})$ which held symmetrical $50 \mathrm{mM} \mathrm{KCl}$ solutions, $\mathrm{pH}=7$, temperature $23 \pm 1^{\circ} \mathrm{C}$. The aqueous solutions were used unbuffered. The salts used in the experiments were of analytical grade. In all peptide experiments performed, the conductance and capacitance of each membrane was tested by applying a voltage of $\pm 100 \mathrm{mV}$ for $10-15$ minutes under stirring to ensure that the membrane was stable.

A stock solution of A $\beta$ P1-40 (Sigma or EZBiolab) was prepared by dissolving $\mathrm{A} \beta \mathrm{P} 1-40$ powder $(0.1 \mathrm{mg})$ in $100 \mu \mathrm{l}$ of bidistilled sterile water under stirring for 3 minutes. From this solution, $5 \mu \mathrm{l}$ were withdrawn and diluted in $45 \mu \mathrm{l}$ of bidistilled sterile water under stirring for 3 minutes. Both solutions were stored at $-20^{\circ} \mathrm{C}$ until use and $8.7 \mu \mathrm{l}$ of the second solution was added to the cis-side of the membrane, to obtain the final concentration of $5 \times 10^{-8} \mathrm{M}$. After A $\beta$ P1-40 ion channel formation, few $\mu$ l of scalar dilution of choline (Fluka) stock solutions $\left(1 \times 10^{-3} ; 1 \times 10^{-5}\right.$; $\left.1 \times 10^{-7} ; 1 \times 10^{-8} \mathrm{M}\right)$ were added to obtain the final desired concentration on the cis or trans side of the Teflon chambers. The solutions were stirred after each addition of $\mathrm{A} \beta \mathrm{P} 1-40$ or choline for 1 minute.

In single-channel experiments, the membrane current was monitored with an oscilloscope and recorded on a chart recorder for further data analysis by hand. The cis and trans chambers were connected to the amplifier head stage by $\mathrm{Ag} / \mathrm{AgCl}$ electrodes in series with a voltage source and a highly sensitive current amplifier. The single-channel instrumentation had a time resolution of 1-10 msec depending on the magnitude of the single-channel conductance. The polarity of the voltage was defined according to the side where $\mathrm{A} \beta \mathrm{P}$ was added (the cis-side). A trans-negative potential (indicated by a minus sign) means that a negative potential was applied to the trans side, the compartment opposite the one where $\mathrm{A} \beta \mathrm{P}$ was added.

The phenomenology of $\mathrm{A} \beta \mathrm{P} 1-40$ incorporation and choline action was studied as follows:

(i) to define the voltage-dependent characteristics of $\mathrm{A} \beta \mathrm{P} 1-40$, we measured the amplitude of channel events at each membrane potential applied,

(ii) to define the channel lifetime, from records extending over prolonged periods, the channel duration was measured considering the time between the opening and closing of each channel. The single channel data were obtained from at least two and sometimes four experiments (more than 100 single channels for each experiment) performed on different days. A histogram of channel conductance distribution for each experiment was constructed and fitted by a Gaussian distribution function (GraphPad Prism version 3.0; GraphPad Software Inc., http://www.graphpad.com/). Results are expressed as mean \pm SE. The average lifetime of the conductance unit was estimated by the formula

$$
N=A_{1} e^{\left(-t / \tau_{1}\right)}+A_{2} e^{\left(-t / \tau_{2}\right)}
$$

where $N$ is the number of channels that remain open for a time equal to or greater than a certain time $t, A_{1}$ and $A_{2}$ are the zero time amplitudes, and $\tau_{1}$ and $\tau_{2}$ are related to the fast and slow components of the time constant, respectively. The single-exponential distribution is included in the formula $\left(A_{2}=0\right)$. To choose between the two models, we performed an appropriate statistical test (F-test, Graph Pad Prism version 3.0; Graph Pad Software, Inc, http://www.graphpad.com/)

(iii) to identify the charge on the ion carrying the current, we measured the shift in the reversal potential induced by a change from a symmetrical to an asymmetrical $\mathrm{KCl}$ solution system. When the membrane conductance reached a virtually stable value, after addition of $\mathrm{A} \beta \mathrm{P} 1-40$ to the cis chamber,we added choline to the cis or trans side. After stabilizing the membrane conductance, the $\mathrm{KCl}$ concentration was raised to $100 \mathrm{mM}$ by adding concentrated salt solution to the cis side of the chamber. 
The reversal potential was determined by changing the holding potential of $\pm 4 \mathrm{mV}$ step by step, and the potential at which the current was zero was taken as the reversal potential for the open channel.

The permeability ratio was calculated using the Goldman-Hodgkin-Katz equation

$$
V=\left(\frac{R T}{F}\right) * \ln \left\{\frac{\left(P_{K}[K]_{t}+P_{\mathrm{Cl}}[\mathrm{Cl}]_{c}\right)}{\left(P_{K}[K]_{c}+P_{\mathrm{Cl}}[\mathrm{Cl}]_{t}\right)}\right\},
$$

where $[X]_{t}$ and $[X]_{c}$ are the concentrations of the ion species $X$ in the trans and cis compartments, respectively and where $R, T$ and $F$ are molar gas constant, thermodynamic temperature and Faraday constant, respectively.

2.2. Circular Dichroism Measurement. CD spectra were recorded on a Jasco J-810 spectropolarimeter at $23 \pm 1{ }^{\circ} \mathrm{C}$. Cells with a path length of $1 \mathrm{~cm}$ were used for spectra recorded between 200 and $260 \mathrm{~nm}$, with sampling points every $0.5 \mathrm{~nm}$. The $\mathrm{A} \beta \mathrm{P} 1-40$ stock solution concentration was $5.77 \times 10^{-5} \mathrm{M}$. The aqueous buffer used to dissolve the peptide was $50 \mathrm{mM} \mathrm{KCl} \mathrm{pH} \mathrm{7.} \mathrm{Peptide} \mathrm{samples} \mathrm{were}$ prepared from stock solution at a concentration of $5.77 \times$ $10^{-6} \mathrm{M}$ in $50 \mathrm{mM} \mathrm{KCl} \mathrm{pH} \mathrm{7.} \mathrm{Samples} \mathrm{containing} \mathrm{choline} \mathrm{were}$ prepared by adding choline chloride at a concentration of $5.77 \times 10^{-9} \mathrm{M}$ or $5.77 \times 10^{-8} \mathrm{M}$ to the $\mathrm{A} \beta \mathrm{P} 1-40$ samples, the same ratio $(1: 1000$ or $1: 100$, resp.) of choline: $\mathrm{A} \beta \mathrm{P} 1-40$ that was used in channel experiments. CD spectra were recorded 5 minutes, 24, and 48 hours after preparing the samples. Each CD spectrum consisted of five consecutive scans at a scanning speed of $20 \mathrm{~nm} / \mathrm{min}$. The samples were stored at 23 $\pm 1^{\circ} \mathrm{C}$ for subsequent analysis.

2.3. Choline Permeability across OxCh Membrane without and with A PP1-40 Channel Activity. Choline permeability was measured as follows: when the membrane turned "black" in the control experiments or when $\mathrm{A} \beta \mathrm{P} 1-40$ manifested its channel activity and in the open state of the channel, $4 \mu \mathrm{l}$ of ethanol containing $4 \mu \mathrm{Ci}$ of the labelled choline $\left(\left[{ }^{3} \mathrm{H}\right]\right.$ choline, Perkin-Elmer) were added to the cis side; the same amount of unlabeled choline solution was added to the opposite side. The solution was stirred mechanically. After 30 minutes, $10 \mu \mathrm{l}$ of fluid from both sides was collected. The radioactivity readings were performed with an LS 6500 Multipurpose Scintillation Counter (Beckman Coulter, USA) and the permeability coefficient calculated. Mean values $\pm \mathrm{SE}$ of 3 experiments for each set of experiments are reported.

\section{Results}

3.1. Effect of Choline on A $\beta P 1-40$ Channel Conductance. In this study, we evaluated the effect of choline on the A $\beta \mathrm{P} 1-40$ ion channel incorporated into PLMs made up of OxCh or POPC: Ch.

First of all, in order to exclude any nonspecific and destabilizing effect of choline per se on PLMs used, we performed experiments by leaving choline in the medium facing the membrane for up to 24 hours. The stability of the
PLM was tested by applying a voltage of $\pm 100 \mathrm{mV}$ for $10-$ 15 minutes under stirring and monitoring constant values for conductance $(25 \mathrm{pS})$ and capacitance $\left(0.32 \mu \mathrm{F} / \mathrm{cm}^{2}\right)$; choline, over the range of concentrations used in the present work, caused no variations in membrane conductance and capacitance in bare membranes.

The incorporation of $\mathrm{A} \beta \mathrm{P} 1-40$ (added to the cis side of the medium facing the membrane) into the lipid bilayer leads to nonrandom discrete square events that fluctuate between conductive and nonconductive states, compatible with channel-type openings, and closures with different conductance levels, lifetime and frequency. The pattern is similar to that found in our previous study [14], that is, we found higher conductance for the $\mathrm{A} \beta \mathrm{P} 1-40$ channel incorporated into OxCh PLM. Figure 1 shows examples of chart recordings of $\mathrm{A} \beta \mathrm{P} 1-40$ channel formation in OxCh PLMs.

When the $\mathrm{A} \beta \mathrm{P} 1-40$ channels fluctuated in the open state in OxCh PLMs, choline $\left(5 \times 10^{-11} \mathrm{M}\right)$ was added to the cis or trans side of the medium facing the membrane. In a short time (about 5/30 minutes, cis/trans, resp.) choline determined an increase in $\mathrm{A} \beta \mathrm{P} 1-40$ ion channel activity characterized by more frequent multiple levels of conductance. Furthermore, these patterns were more evident at positive applied voltages. Figure 2 reports the histograms of conductance distribution for each experimental condition used in OxCh PLMs. All the histograms show single-peaked conductance distributions. The central value of conductance $\left(\Lambda_{c}\right)$ obtained by the Gaussian best-fit characterizes the conductance state of $\mathrm{A} \beta \mathrm{P} 1-40$ channels in various membranes. Figure 3(a) reports the central value of $\Lambda_{c} \pm \mathrm{SE}$ at the different applied voltages for different experimental conditions in OxCh PLMs. In the presence of choline, no matter which side it is added, the $\Lambda_{c}$ values are significantly higher at positive applied voltages than at negative ones $(P<.0001$ and $P \leq .0012$ for choline added on the $c i s$ and on the trans side, resp.). If we compare the effect of choline on $\mathrm{A} \beta \mathrm{P} 1-40$ channel conductance, it can be seen that choline added on the trans side increases channel conductance more than when added to the cis side.

Figure 4 shows typical examples of single-channel chart recordings of $\mathrm{A} \beta \mathrm{P} 1-40$ channel formation with associated conductance distribution histograms in OxCh PLMs without and with successive additions of choline to the cis-side of the medium facing the membrane or when choline in a ratio of about $1: 3$ to the peptide $\left(1.5 \times 10^{-8} \mathrm{M}\right)$ was added when the channel was fluctuating in the open state. It can be seen that single-channel activity sometimes occurred in highly variable steps, yet the frequency of channels increases by increasing the choline concentration; we also observed alternating periods of paroxystic channel activity, during which it is impossible to make a rigorous analysis of the number of channels, followed by quiescent periods that are more frequents at higher choline concentration and often followed by membrane destabilization until rupture. Furthermore, a $t$-test showed that the central channel conductance of $\mathrm{A} \beta \mathrm{P} 1$ 40 is statistically increased when choline at different concentrations is added to the cis-side (see capture of Figure 4). Yet, the same result was found when choline at different concentrations was added to the trans side (data not shown). 


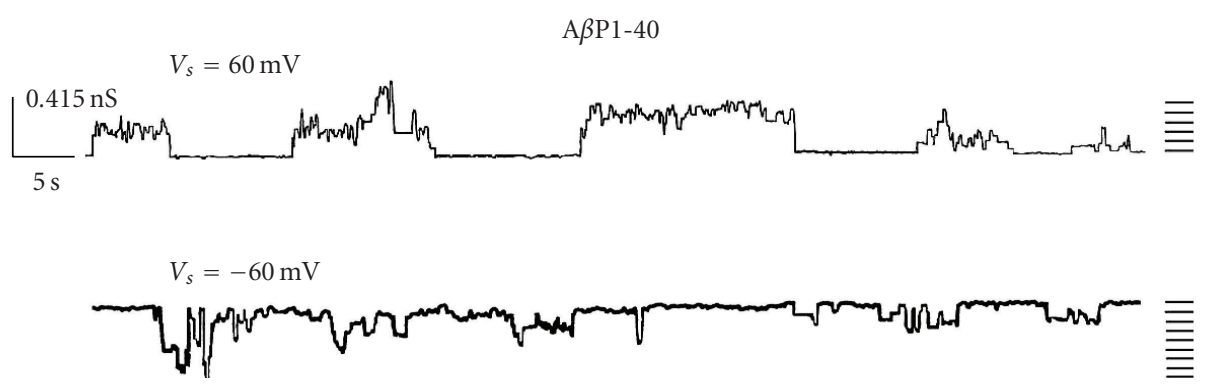

(a)

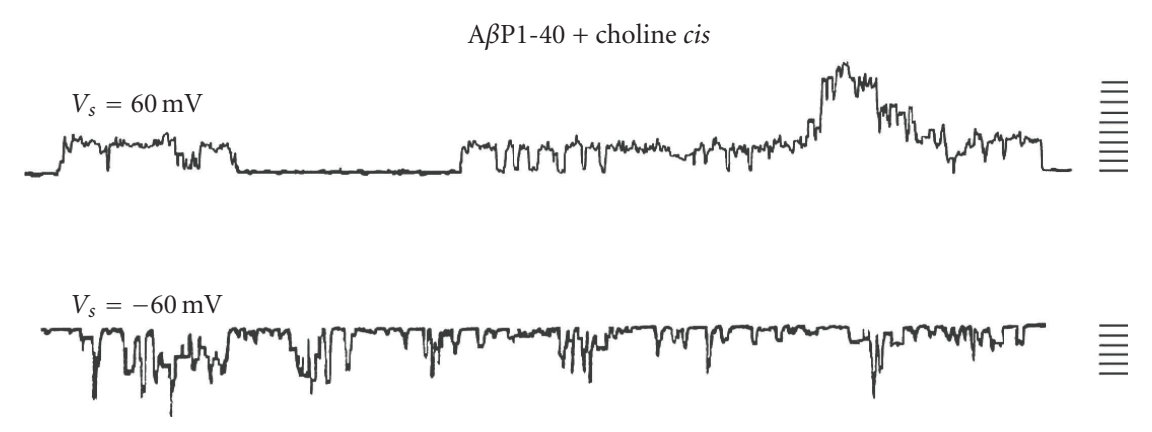

(b)

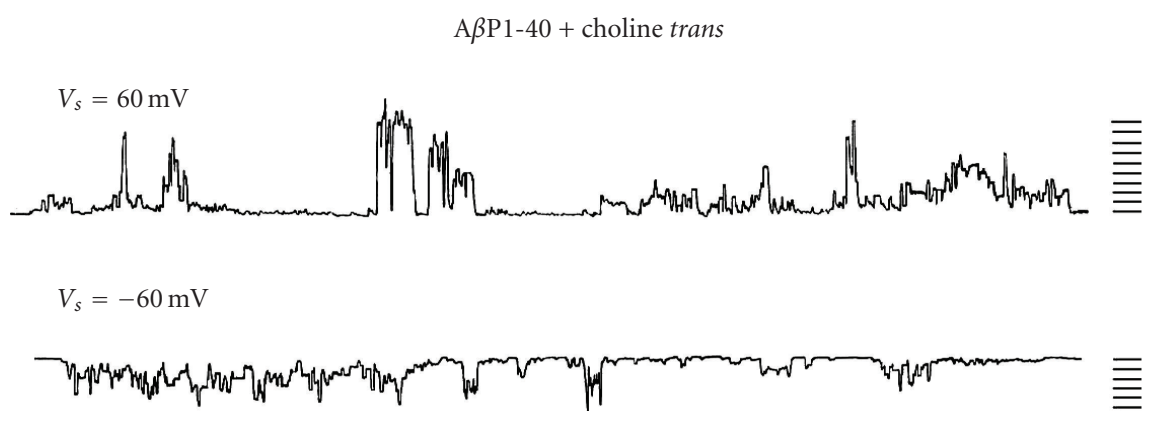

(c)

FIGURE 1: A $\beta$ P1-40 channel activity in OxCh PLM in the absence and in the presence of choline. Representative A $\beta$ P1-40 channel in the absence (a), in the presence of choline on the cis (b), or on the trans (c) side of the medium facing an OxCh PLM at an applied voltage of $\pm 60 \mathrm{mV}$. Each trace represents a fragment of the recording of the activity obtained in individual experiments. Note the increased activity of the channel and the frequent multiple levels of conductance, especially at positive applied voltages, when choline is present. Experimental conditions $\mathrm{KCl} 50 \mathrm{mM}, \mathrm{A} \beta \mathrm{P} 1-405 \times 10^{-8} \mathrm{M}$ were present to the cis side of the membrane, choline $5 \times 10^{-11} \mathrm{M}$ was added on the cis or trans side of the membrane.

Figure 5 shows examples of chart recordings of $A \beta P 1-40$ channel formation in POPC:Ch PLMs. In these PLMs, no matter if choline is added to the cis or the trans side of the membrane, it does not increase A $\beta$ P1-40 ion channel activity or conductance, nor does it modify the voltage dependence and the $\Lambda_{c}$ values of the A $\beta$ P1-40 channel (Figure 6(a)). The $\Lambda_{c}$ values of the A $\beta$ P1-40 channel in POPC: Ch PLMs are lower than those in OxCh PLMs.

Our results indicate that the presence of choline (on the cis or trans side) does not modify the voltage dependence of $\mathrm{A} \beta \mathrm{P} 1-40$ channels in OxCh or POPC: OxCh PLMs (Figures $3(\mathrm{a})$ and $6(\mathrm{a}))$.

3.2. Effect of Choline on AßP1-40 Channel Frequency and Lifetime. The A $\beta \mathrm{P} 1-40$ frequency values are generally higher at positive than those at negative applied voltages in $\mathrm{OxCh}$ PLMs (Figure 3(b)). Adding choline $\left(5 \times 10^{-11} \mathrm{M}\right)$ to the cis or trans side doubled and trebled, respectively, the mean frequency values of the $\mathrm{A} \beta \mathrm{P} 1-40$ channel at positive applied voltages. On the other hand, at negative applied voltages, choline exerts no effect on A $\beta$ P1-40 channel frequency, either when present on the cis or on the trans side of the medium facing the membrane. The frequency increases as a function of choline concentration, and this increase occurs early. In fact, the frequency of $\mathrm{A} \beta \mathrm{P} 1-40$ channel was: $7.73 \pm 0.34$ without choline, $15.97 \pm 0.53$ for a choline concentration of $5 \times 10^{-11} \mathrm{M}, 10.56 \pm 0.40$ for a choline concentration of $1 \times 10^{-10} \mathrm{M}$, and $11.85 \pm 0.60$ for a choline concentration of $1.5 \times 10^{-18} \mathrm{M}$. It is worth noting that these last two values are underestimated owing to the paroxystic activity (see 


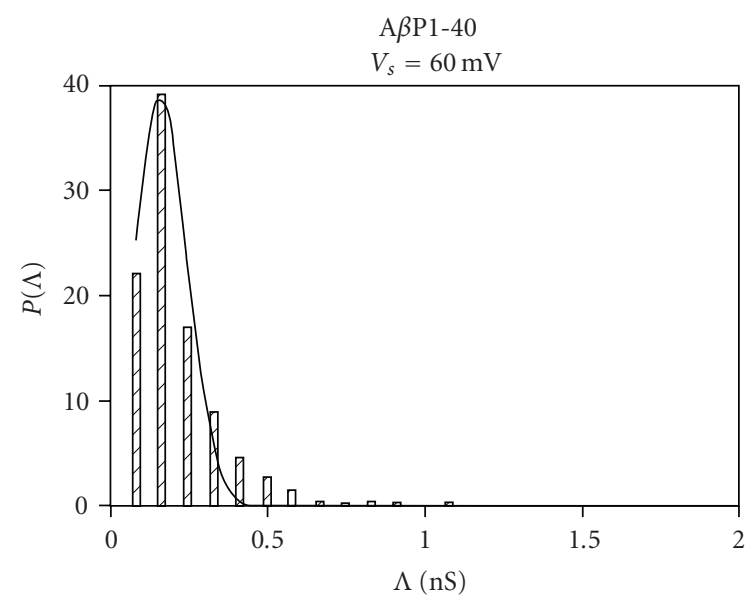

(a)

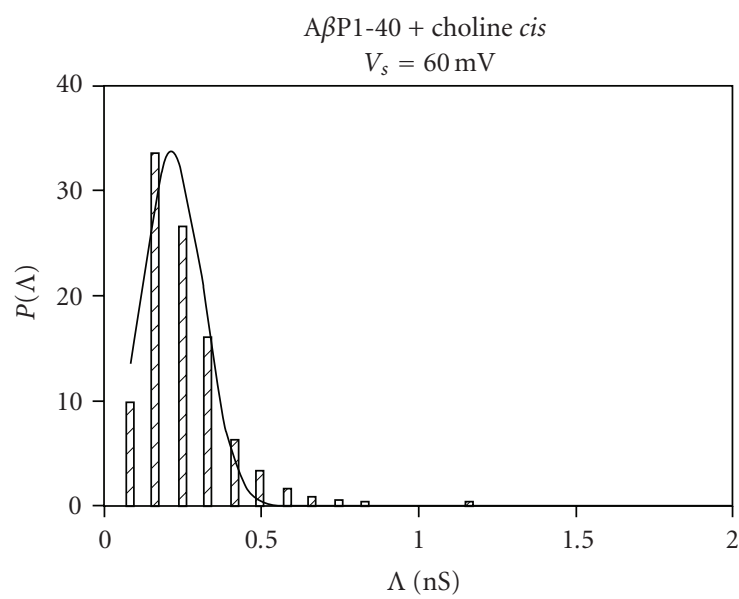

(c)

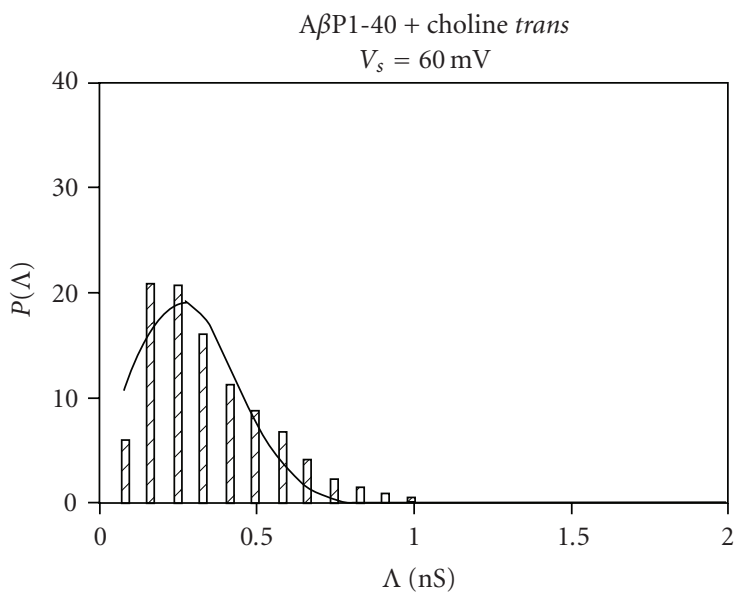

(e)

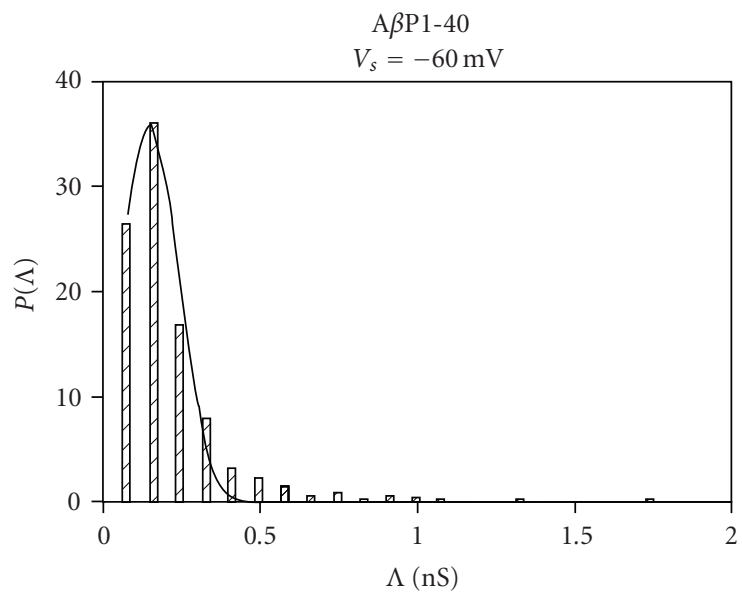

(b)

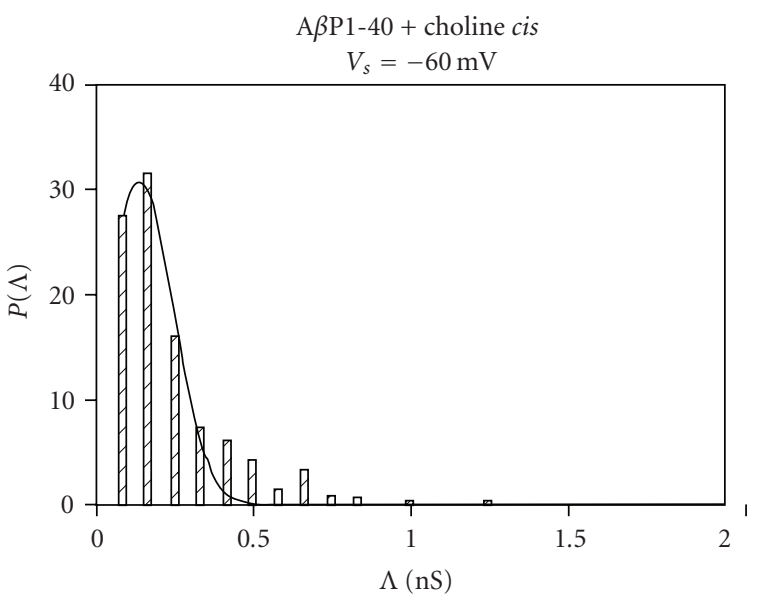

(d)

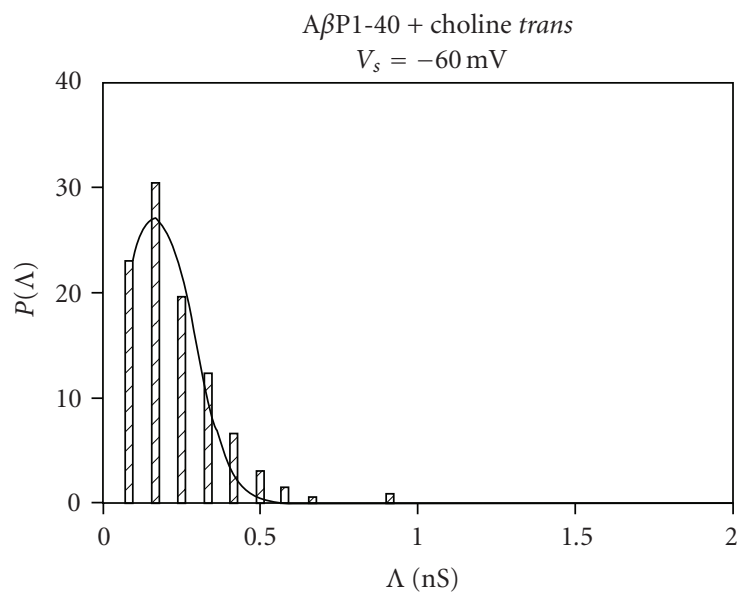

(f)

Figure 2: Amplitude histograms of A $\beta$ P1-40 channel conductance. The histograms of the probability, $\mathrm{P} \Lambda$, for the frequency of a given conductivity unit, relatives to each trace reported in Figure 1, were fitted by a Gaussian which is shown as a solid curve. 


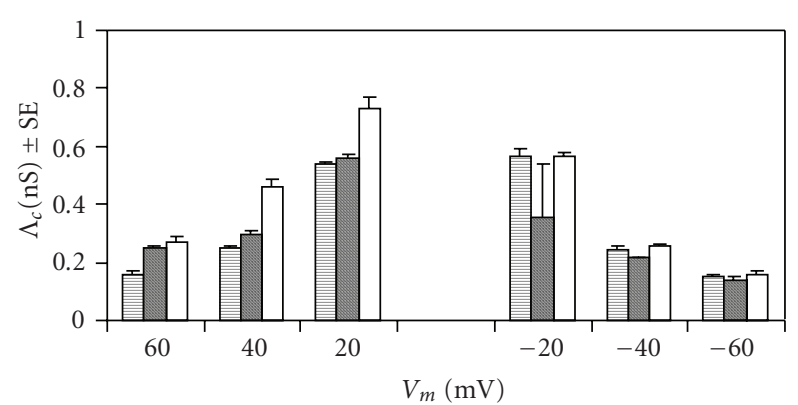

(a)

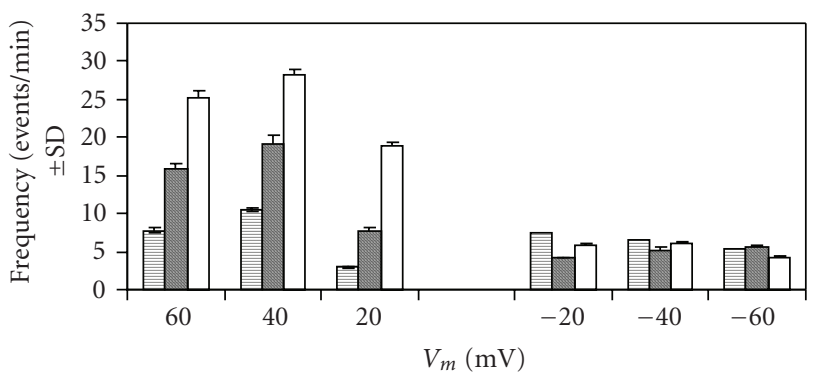

目 $\mathrm{A} \beta \mathrm{P}$
$\square \mathrm{A} \beta \mathrm{P}+\mathrm{Ch}($ cis $)$
$\square \mathrm{A} \beta \mathrm{P}+\mathrm{Ch}($ trans $)$

(b)

Figure 3: A $\beta$ P1-40 channel mean conductance and frequency in OxCh PLM in the absence and in the presence of choline. (a) $\Lambda_{c} \pm$ $\mathrm{SE}$ and (b) frequency \pm SD of $\mathrm{A} \beta \mathrm{P} 1-40$ channel without and with choline $\left(5 \times 10^{-11} \mathrm{M}\right)$ added to the cis or trans side of the chamber in OxCh PLM. The minimum and maximum number of channels considered $(N)$ out of a total number of channels considered $\left(N_{t}\right)$ was: A $\beta$ P1-40, $448<N<2080, N_{t}=5493$; A $\beta$ P1-40 + choline cis, $115<N<898, N_{t}=2269 ; \mathrm{A} \beta \mathrm{P} 1-40+$ choline trans, $448<$ $N<948, N_{t}=3844$.

Figure 4). In POPC: Ch PLMs, A $\beta$ P1-40 channel frequency is not sensitive to the presence of choline on the cis or trans side of the membrane (Figure 6(b)).

Another parameter used to characterize a channel is its lifetime. Single-channel current recordings with a conspicuous number of channels were analysed to obtain cumulative open-state lifetime distributions that are reported for the different experimental conditions. In OxCh PLMs, analysis of the open-time distributions for $\mathrm{A} \beta \mathrm{P} 1-40$ single channels is reported in Table 1, where the functions with statistically significant better description are indicated. It can be noted that at positive applied voltages the fast channel lifetime component prevails $(P<.05)$, whereas at negative applied voltages the channel manifests both the fast and slow components of lifetime $(P<.05)$, except for at $-20 \mathrm{mV}$ where it does not clearly distinguish between single and double exponentials $(P=.102)$.

When choline is on the cis or trans side, the results of the open time distribution analysis for all positive and for low negative applied voltages indicate a statistically significant better description $(P<.05)$ for two-exponential functions; except for -40 and $-60 \mathrm{mV}$ (choline cis) and $-60 \mathrm{mV}$ (choline trans) where there is a statistically significant better description $(P<.05)$ for one-exponential functions, however the values of $\tau_{1}$ in the presence of choline are higher than that of $A \beta \mathrm{P} 1-40$. The prevalence of dual channel populations or the higher values of $\tau_{1}$ clearly indicates that choline (either cis or trans) seems to stabilize the A $\beta \mathrm{P} 1-40$ single channel.

In POPC: Ch PLMs, analysis of the open-time distribution for $\mathrm{A} \beta \mathrm{P} 1-40$ single channels does not clearly distinguish between single and double exponentials (at applied voltages in this study) $(P \geq .078)$. When choline is on the cis side, the results of open-time distribution analysis indicate a statistically significant better description $(P<.05)$ for oneexponential functions, except at applied voltages of $100 \mathrm{mV}$ where it does not clearly distinguish between single and double exponentials $(P=.39)$. When choline is on the trans side, the results of open time distribution analysis give a statistically significant better description $(P<.05)$ for a one-exponential function at an applied voltage of 60 $\mathrm{mV}$, whereas it does not clearly distinguish between single and double exponentials at an applied voltage of $80 \mathrm{mV}$ $(P=.37)$. At an applied voltage of $100 \mathrm{mV}$, the number of channels is not conspicuous enough to provide a reliable analysis of open-time distribution (Table 2). In any case, the addition of choline, either on the cis or the trans side, does not seem to modify the lifetime and stability of the ion channel.

3.3. Ion Selectivity. The ion selectivity of $\mathrm{A} \beta \mathrm{P}$ channels in OxCh or POPC:Ch membranes in the presence of choline in the cis or trans medium was determined by means of reversal potential and $I-V$ relationship at different transmembrane potentials under asymmetrical solution conditions (see methods).

In OxCh PLMs, the $P_{K}{ }^{+} / P_{\mathrm{Cl}}{ }^{-}$calculated by (2) was $0.50 / 0.38$ cis/trans, respectively.

Approximately the same result was obtained with the $I-V$ curve (Figure 7), where the amplitude of the channel events at each membrane potential was used. In fact, the reversal potential was $6.42 \mathrm{mV}$ with choline in the cis chamber and $6.87 \mathrm{mV}$ with choline in the trans chamber; the selective ratio $P_{K}{ }^{+} / P_{\mathrm{Cl}}{ }^{-}$was $0.46 / 0.43$ cis/trans, respectively. These results seem to indicate that the ion selectivity toward anions of the $\mathrm{A} \beta \mathrm{P} 1-40$ channel in OxCh PLMs [14] is not modified by the presence of choline.

The ion selectivity of the A $\beta$ P1-40 channel in POPC:Ch PLMs remains anionic; in fact, the reversal potential was $9.76 \mathrm{mV}$ and the $P_{K}{ }^{+} / P_{\mathrm{Cl}}{ }^{-}$was 0.28 .

When choline was present on the cis/trans side the reversal potential was $5.76 / 7.76 \mathrm{mV}$ and the $P_{K}{ }^{+} / P_{\mathrm{Cl}}{ }^{-}$was $0.50 / 0.38$ respectively. Approximately the same result was obtained with the $I-V$ curve (Figure 8 ). In fact, the reversal potential was $8.99 \mathrm{mV}$ in the absence of choline, with a selective ratio $P_{K}{ }^{+} / P_{\mathrm{Cl}}{ }^{-}$of 0.32 . The reversal potential was $6.67 \mathrm{mV}$ with choline in the cis chamber and $6.47 \mathrm{mV}$ with choline in the trans chamber; with a selective ratio $P_{K}{ }^{+} / P_{\mathrm{Cl}}{ }^{-}$ of $0.44 / 0.45$ cis/trans, respectively. 

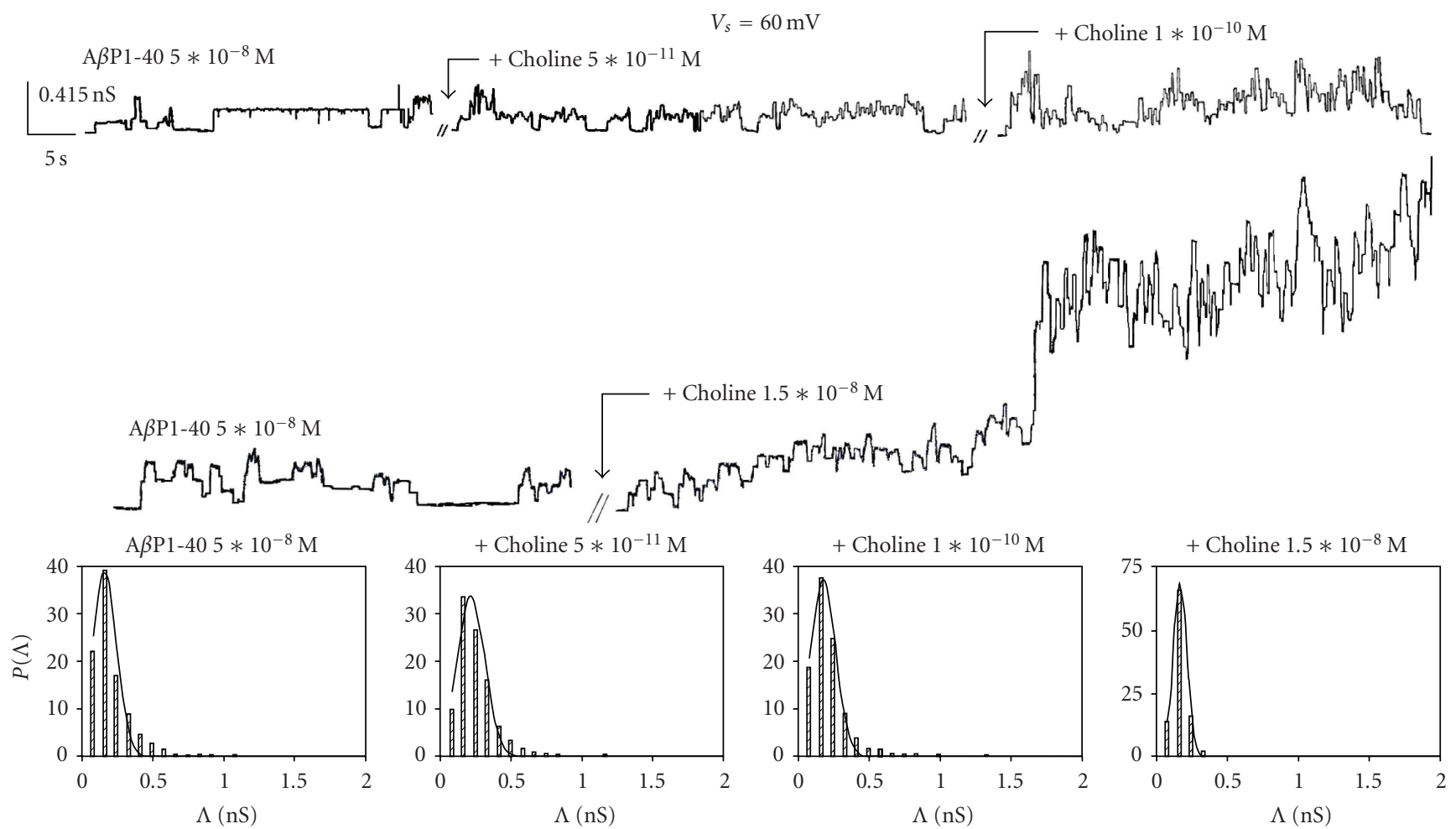

FIGURE 4: A $\beta$ P1-40 channel activity in OxCh PLM in the absence and in the presence of different choline concentrations. Experiments were performed on an OxCh PLM in the presence of different concentrations of choline added or in the presence of high choline concentrations on the cis-side of the medium; the applied voltage was set at $60 \mathrm{mV}$; the arrows indicate the choline additions when the A $\beta \mathrm{P} 1-40$ channel fluctuates in the open state. The channel central conductance $(\mathrm{nS} \pm \mathrm{SE}) /$ frequency (events/min $\pm \mathrm{SD}$ ) without and with choline added to the medium was: $\mathrm{A} \beta \mathrm{P} 1-40=0.161 \pm 0.008 / 7.73 \pm 0.34 ; \mathrm{A} \beta \mathrm{P} 1-40+$ choline $\left(5 \times 10^{-11} \mathrm{M}\right)=0.215 \pm 0.007 / 15.97 \pm 0.53 ; \mathrm{A} \beta \mathrm{P} 1-40+$ choline $\left(1 \times 10^{-10} \mathrm{M}\right)=0.179 \pm 0.004 / 10.56 \pm 0.40 ; \mathrm{A} \beta \mathrm{P} 1-40+$ choline $\left(1.5 \times 10^{-8} \mathrm{M}\right)=0.168 \pm 0.001 / 11.85 \pm 0.60$. The number of channel considered was: $\mathrm{A} \beta \mathrm{P} 1-40=505 ; \mathrm{A} \beta \mathrm{P} 1-40+$ choline $\left(5 \times 10^{-11} \mathrm{M}\right)=898 ; \mathrm{A} \beta \mathrm{P} 1-40+$ choline $\left(1 \times 10^{-10} \mathrm{M}\right)=652 ; \mathrm{A} \beta \mathrm{P} 1-40+$ choline $(1.5$ $\left.\times 10^{-8} \mathrm{M}\right)=358$. Amplitude histograms of channel conductance for each trace are shown below traces.

TABLE 1: The channel lifetime of A $\beta$ P1-40 in OxCh PLM. The fitted lifetime (see text) of A $\beta$ P1-40 in the absence (a) and in the presence of choline $\left(5 \times 10^{-11} \mathrm{M}\right)$ added on the cis/trans side of the medium facing the OxCh PLM (b/c, resp.). The minimum and maximum number of channels considered $(N)$ out of a total number of channels considered $\left(N_{t}\right)$ was: (a) $125<N<503, N_{t}=1214$; (b) $95<N<217$, $N_{t}=834$; (c) $102<N<186, N_{t}=857$. F-test, ${ }^{*} P=.102$.

\begin{tabular}{|c|c|c|c|c|c|c|}
\hline \multirow{2}{*}{ Vs $(\mathrm{mV})$} & \multicolumn{2}{|c|}{$\mathrm{a}$} & \multicolumn{2}{|c|}{$\mathrm{b}$} & \multicolumn{2}{|c|}{ c } \\
\hline & $\tau_{1}(\mathrm{~s})$ & $\tau_{2}(\mathrm{~s})$ & $\tau_{1}(\mathrm{~s})$ & $\tau_{2}(\mathrm{~s})$ & $\tau_{1}(\mathrm{~s})$ & $\tau_{2}(s)$ \\
\hline 60 & 2.07 & & 1.53 & 8.34 & 1.45 & 7.76 \\
\hline 40 & 3.56 & & 1.88 & 19.61 & 1.58 & 8.46 \\
\hline 20 & 1.12 & & 1.29 & 20.01 & 1.17 & 6.49 \\
\hline-20 & $1.05^{*}$ & & 2.23 & 32.26 & 0.25 & 5.03 \\
\hline-40 & 1.17 & 4.96 & 3.69 & & 0.15 & 3.94 \\
\hline-60 & 1.33 & 8.99 & 2.23 & & 2.54 & \\
\hline
\end{tabular}

3.4. Effect of Choline on AßP1-40 Secondary Structure. To test whether choline modifies the secondary structure of $\mathrm{A} \beta \mathrm{P} 1-40$, we carried out $\mathrm{CD}$ experiments using $\mathrm{A} \beta \mathrm{P} 1-40$ samples in the absence or in the presence of choline in a molar ratio of $1: 100$ and $1: 1000$ choline: A $\beta$ P. Figure 9 shows the CD spectra of $\mathrm{A} \beta \mathrm{P} 1-40$ without and with choline measured after 5 minutes (T0), 24 hours (T24), and 48 hours (T48).
The CD spectra qualitatively indicate that $\mathrm{A} \beta \mathrm{P} 1-40$ conformation in an aqueous environment is predominantly $\beta$-sheet and random coil, while the $\alpha$-helical content is very small. Our results are in line with other authors' findings [11]. The features of the spectra show that choline at the two concentrations used does not modify the secondary structure of the peptide. Moreover, it increases the signal intensity after 24 and 48 hours of incubation. This could mean 


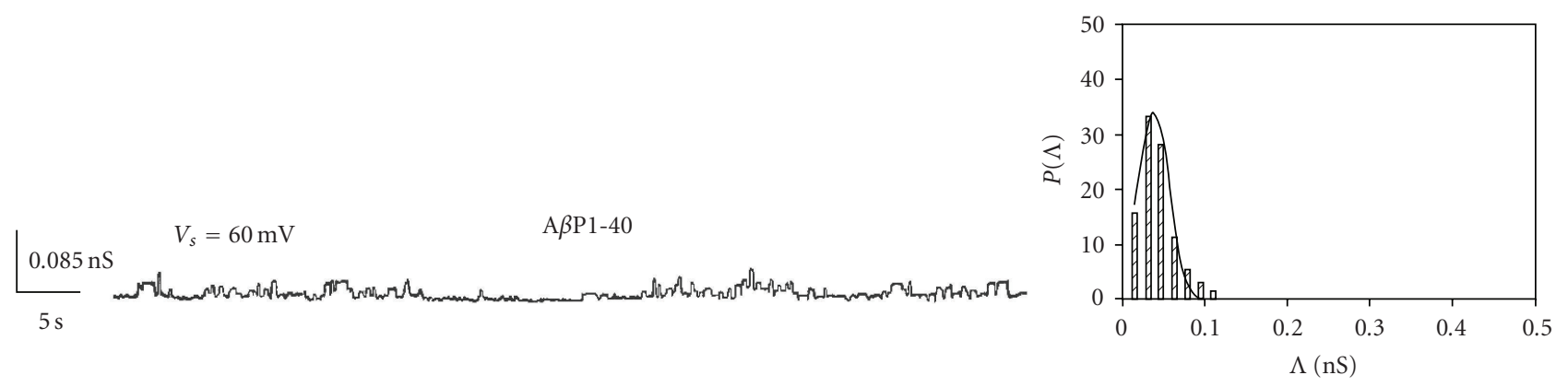

(a)
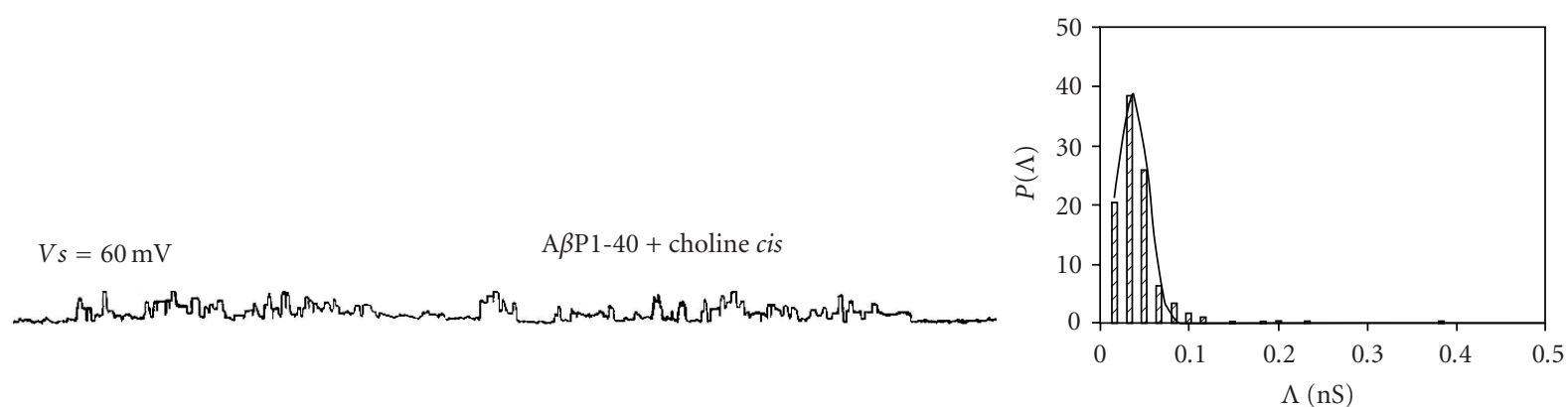

(b)

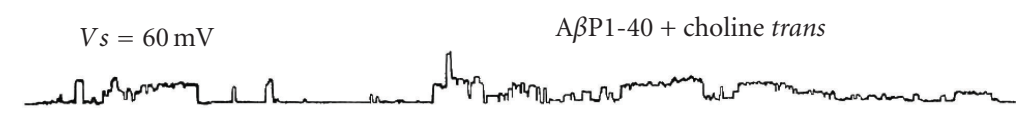

(c)

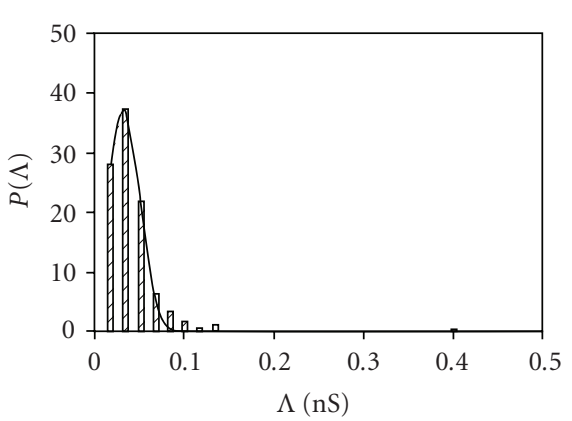

Figure 5: A $\beta$ P1-40 channel activity in POPC:Ch PLM. Representative A $\beta$ P1-40 channel in the absence (a) or in the presence of choline $\left(5 \times 10^{-11} \mathrm{M}\right)$ on the $c$ is $(\mathrm{b})$ or on the trans (c) side of the medium facing a POPC:Ch $(65: 35, \mathrm{w} / \mathrm{w})$ PLM at an applied voltage of $60 \mathrm{mV}$. Amplitude histograms of channel conductance for each trace are shown next to their respective traces.

TABLE 2: The channel lifetime of A $\beta$ P1-40 in POPC:Ch PLM. The fitted lifetime (see text) of A $\beta$ P1-40 (a), A $\beta$ P1-40 and choline (5 $\times 10^{-11}$ M) added to the cis/trans side of the chamber (b/c, resp.) channels in the POPC:Ch membrane. The minimum and maximum number of channels considered $(N)$ out of a total number of channels considered $\left(N_{t}\right)$ was: (a) $94<N<240, N_{t}=448$; (b) $120<N<196$, $N_{t}=435$; (c) $19<N<111, N_{t}=205$. F-test, ${ }^{*} P \geq .078$; ${ }^{*} P=.39$; ${ }^{* *} P=0.37$.

\begin{tabular}{lccc}
\hline $\mathrm{Vs}(\mathrm{mV})$ & $\mathrm{a}$ & $\mathrm{b}$ & $\mathrm{c}$ \\
& $\tau_{1}^{*}(\mathrm{~s})$ & $\tau_{1}(\mathrm{~s})$ & $\tau_{1}(\mathrm{~s})$ \\
\hline 100 & 2.50 & $1.72^{* *}$ & - \\
80 & 3.13 & 3.03 & $2.99^{* * *}$ \\
60 & 3.25 & 2.32 & 3.11 \\
\hline
\end{tabular}

that choline stabilizes the $\mathrm{A} \beta \mathrm{P} 1-40$ structure, counteracting peptide aggregation.

3.5. Choline Permeability across Undoped and Doped OxCh Membranes. Control experiments were designed to test the effect of ethanol on membrane integrity. The addition of $4 \mu \mathrm{l}$ of ethanol to both sides of the OxCh membrane, under stirring, does not influence the capacitance $\left(0.32 \mu \mathrm{F} / \mathrm{cm}^{2}\right)$ and the conductance $(25 \mathrm{pS})$ of the membrane over a long period of time (about 6 hours). 


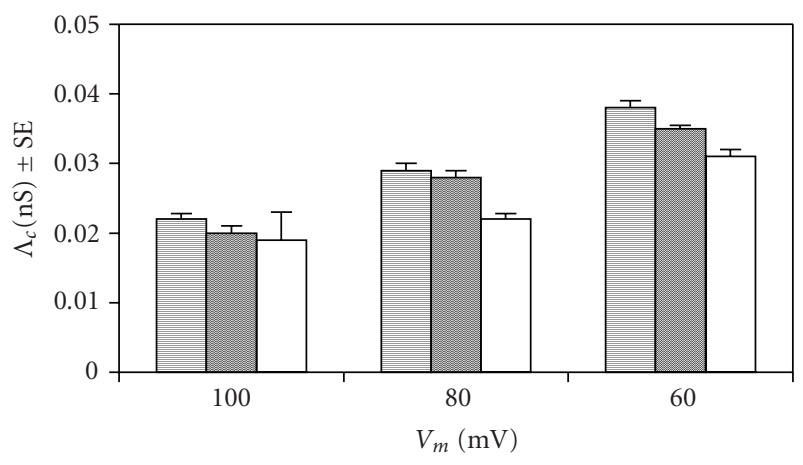

(a)

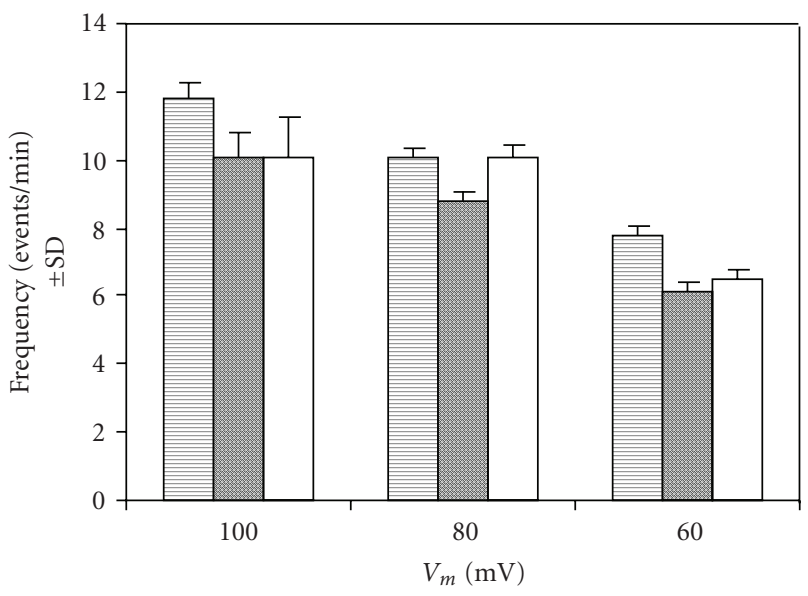

$$
\begin{aligned}
& \square \mathrm{A} \beta \mathrm{P} \\
& \square \mathrm{A} \beta \mathrm{P}+\mathrm{Ch}(\text { cis }) \\
& \square \mathrm{A} \beta \mathrm{P}+\mathrm{Ch}(\text { trans })
\end{aligned}
$$

(b)

FIGURE 6: A $\beta$ P1-40 channel mean conductance and frequency in POPC:Ch PLM. (a) $\Lambda_{c} \pm$ SE and (b) frequency \pm SD of A $\beta$ P $1-40$ channel without and with choline $\left(5 \times 10^{-11} \mathrm{M}\right)$ (added to the cis or trans side of the chamber) in POPC:Ch $(65: 35, w / w)$ PLM. The minimum and maximum number of channels considered $(N)$ out of a total number of channels considered $\left(N_{t}\right)$ was: A $\beta$ P1-40, $761<$ $N<1283, N_{t}=$ 2928; A $\beta$ P1-40 + choline cis, $449<N<1320$, $N_{t}=2305 ; \mathrm{A} \beta \mathrm{P} 1-40+$ choline trans, $170<N<624, N_{t}=$ 1269 .

The permeability coefficients of $\left[{ }^{3} \mathrm{H}\right]$ choline across the OxCh membrane, undoped and doped with $\mathrm{A} \beta \mathrm{P} 1-40$, were: $47.1 \pm 2.14$ and $43.8 \pm 7.9\left(\mathrm{~cm} \times \sec ^{-1} \times 10^{-6}\right)$, respectively.

This data indicates that choline, despite showing a high permeability coefficient across $\mathrm{OxCh}$ membranes, is unable to cross the $\mathrm{A} \beta \mathrm{P} 1-40$ channel.

\section{Discussion}

Early evidence showed that $\mathrm{A} \beta \mathrm{P} 1-40$ is initially deposited on the membranes and acts as a "seed" for the formation of fibrils [19], although the involvement of $\mathrm{A} \beta \mathrm{P}$ fibrillation in vivo in the process of neurodegeneration and the development of $\mathrm{AD}$ is not an irrefutable criterion for defining the pathology. Recent studies have shown that $\mathrm{A} \beta \mathrm{P}$ induces toxicity on

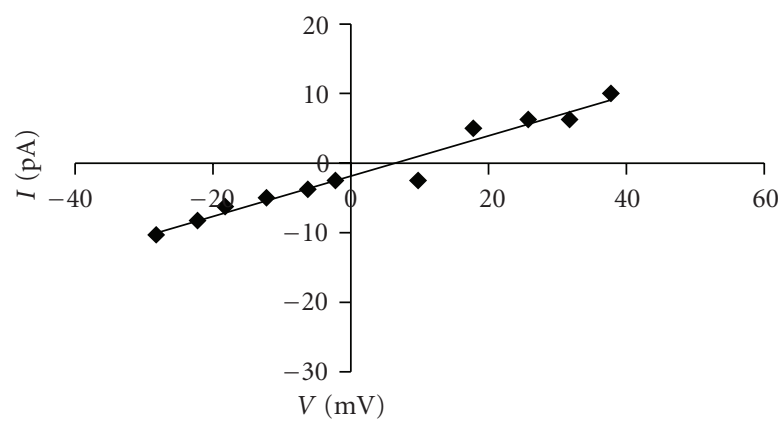

(a)

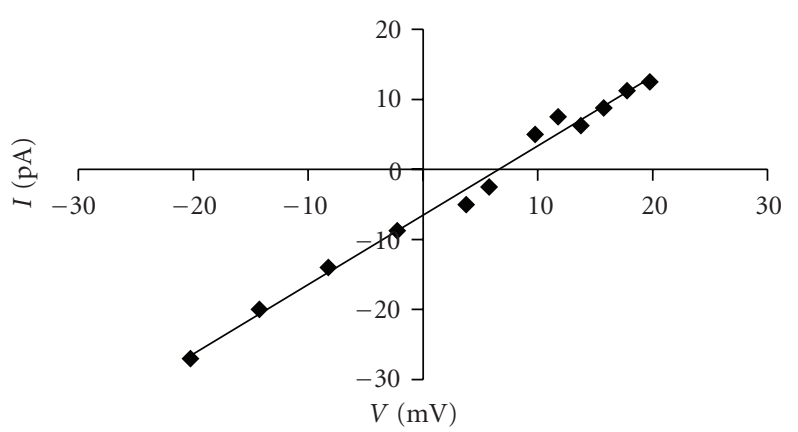

(b)

FIgure 7: A $\beta$ P1-40 channel ion selectivity in OxCh PLM. A $\beta$ P1-40 channel selectivity in the presence of choline $\left(5 \times 10^{-11} \mathrm{M}\right)$ cis (a) or trans (b) in OxCh PLM. The amplitude of the channel current (pA) is plotted as a function of the transmembrane potential $(V)$. Conductance was determined by linear regression of the current values from $-30 /-20 \mathrm{mV}$ to $40 / 20 \mathrm{mV}$ (choline cis/trans) in asymmetrical solutions $100 \mathrm{mM} / 50 \mathrm{mM} \mathrm{KCl}$ cis/trans. Intercept (5.76/7.76 mV, choline cis/trans) was used to calculate $P_{K}{ }^{+} / P_{\mathrm{Cl}}{ }^{-}$.

cholinergic neurons in vitro and in vivo by increasing, via distinct mechanisms, Ach turnover. In neuronal cells, choline is a precursor of ACh, but also a product of ACh hydrolysis after the neurotransmission process. The mechanisms involved in cholinergic dysfunction are under intense investigation because of their potential therapeutical implications [20]. Although the basal extracellular choline concentration is higher (about $5 \mu \mathrm{M}$ ) [21] as compared to the concentration used in the present study, the sensitivity of our experimental system, suitable for high-resolution ion current recordings, does not allow us to use choline concentration higher than $1.5 \times 10^{-8} \mathrm{M}$. In fact, the activation of $\mathrm{A} \beta \mathrm{P}$ channels by choline at concentration higher than 1.5 $\times 10^{-8} \mathrm{M}$ generates an electrical signal that is so large that it exceeds the maximum level of detection by the recording system furthermore, these conditions will lead to membrane instability eventually resulting in membrane breakage.

The human brain contains as much as $25 \%$ of the total pool of Ch, mainly concentrated in the myelin sheath. However, there are also considerable amounts of $\mathrm{Ch}$ in neuronal plasmalemma and in lipid rafts. One interesting aspect of the $\mathrm{Ch}$ molecule seems to be its affinity for many proteins such as porins [22, 23], for peptides such as magainin2 [24], $\mathrm{A} \beta \mathrm{P} 1-40$ and $\mathrm{A} \beta \mathrm{P} 1-42$ [14], and for peptides associated with myelin; examples of $\mathrm{Ch}$-dependent proteins 


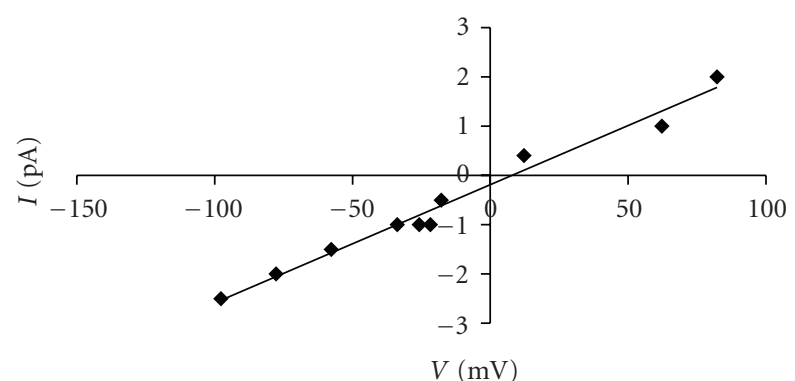

(a)

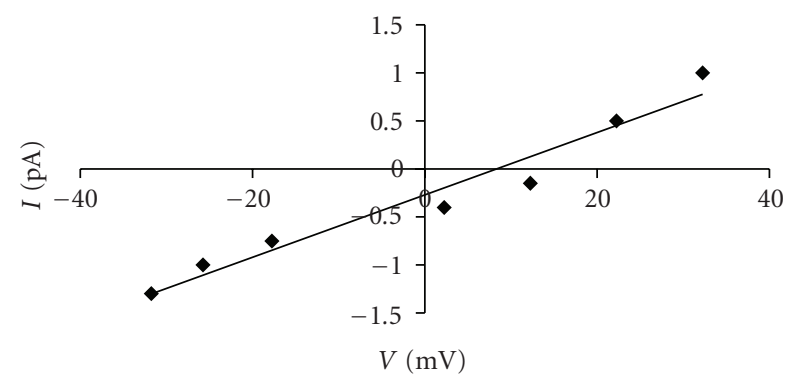

(b)

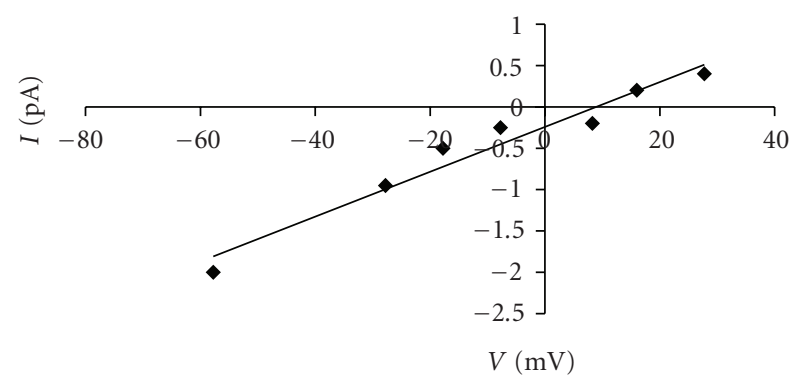

(c)

Figure 8: A $\beta$ P1-40 channel ion selectivity in POPC:Ch PLM. A $\beta$ P1-40 channel selectivity (a), in the presence of choline (5 $\left.\times 10^{-11} \mathrm{M}\right)$ cis (b) or trans (c) side in POPC:Ch $(65: 35, \mathrm{w} / \mathrm{w})$ PLM. The amplitude of the channel current $(\mathrm{pA})$ is plotted as a function of the transmembrane potential $(V)$. Conductance was determined by linear regression of the current values from -150 to $100 \mathrm{mV}$ (a) and from $-40 /-80 \mathrm{mV}$ to $40 / 40 \mathrm{mV}$ (choline cis/trans) in asymmetrical $100 \mathrm{mM} / 50 \mathrm{mM} \mathrm{KCl}$ cis/trans solutions. Intercept $(9.76 / 5.76 / 7.76 \mathrm{mV},(\mathrm{a}) /(\mathrm{b}) /(\mathrm{c})$ resp.) was used to calculate $P_{K}{ }^{+} / P_{\mathrm{Cl}}{ }^{-}$.

are prominin, synaptophysin, platelet-derived growth factor receptor, hemolysin, acetylcholine-receptor, peripheral myelin protein 22, and prions [25-31]. In particular, it has been demonstrated that $\mathrm{Ch}$ at a concentration of $33 \%$ in model membranes and in vesicles can favour the transition of $\mathrm{A} \beta \mathrm{P} 1-40$ and human cytoplasmic domain of myelin protein zero into alpha helix [32]. On the other hand, membrane Ch induces the structural conformation of many peptides for incorporation.

Results in $\mathrm{OxCh}$ and POPC: Ch planar lipid membranes (PLMs) confirm our previous findings [14] and further indicate the role played by membrane composition in the alpha-helix structure induction mechanism needed for $\mathrm{A} \beta \mathrm{P}$ incorporation into membranes. Furthermore, we found

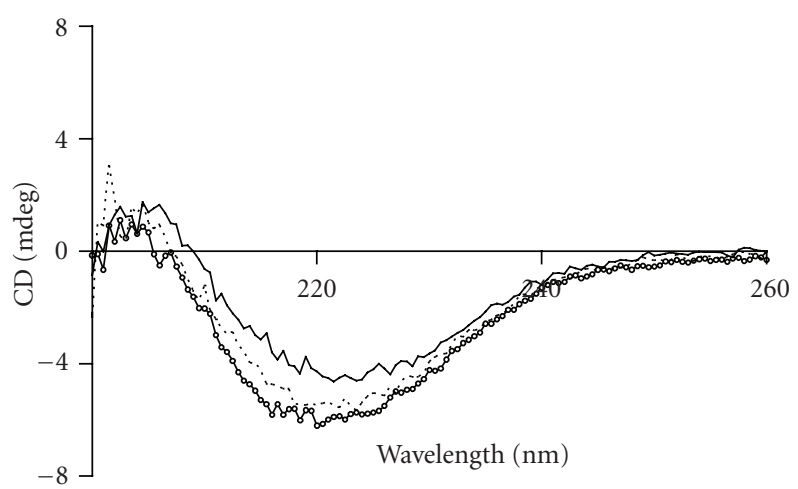

(a)

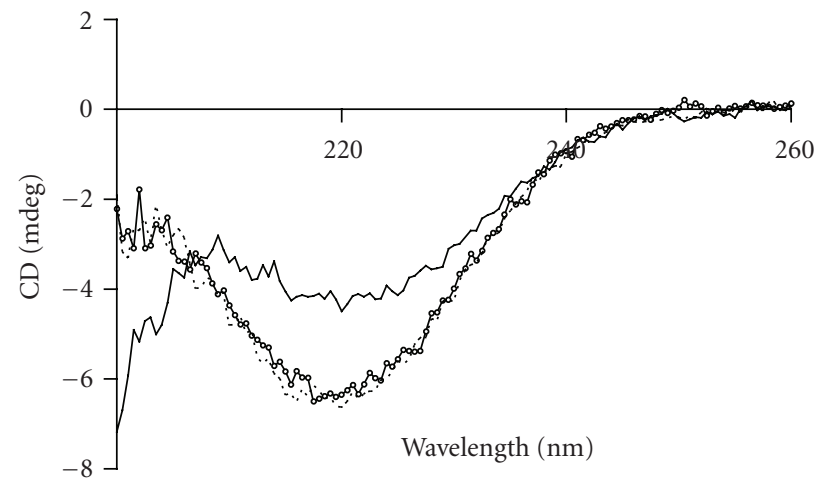

(b)

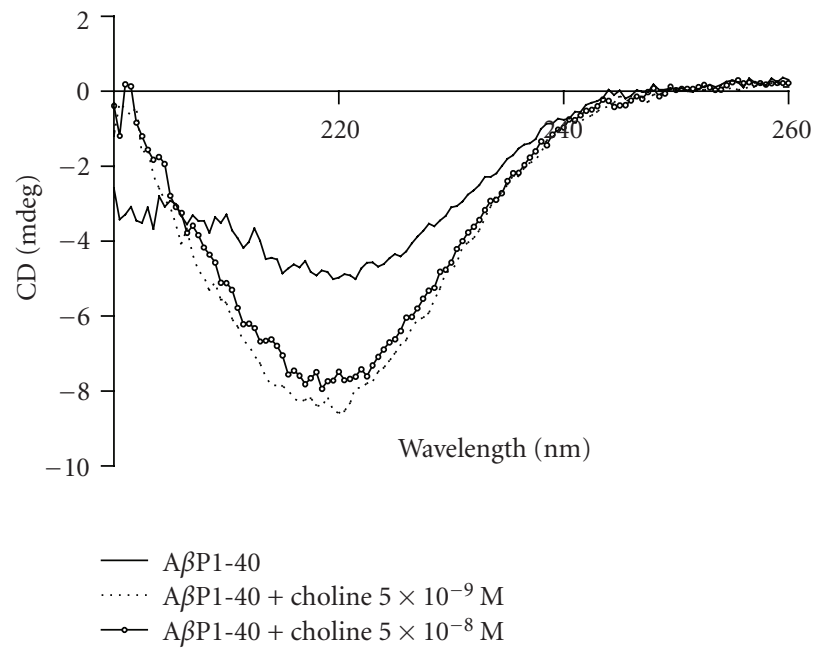

(c)

FIgURE 9: A $\beta$ P1-40 secondary structure. Far-UV CD spectroscopy of $\mathrm{A} \beta \mathrm{P} 1-40\left(5 \times 10^{-6} \mathrm{M}\right)$ in the absence and in the presence of choline $\left(5.77 \times 10^{-8} \mathrm{M} ; 5.77 \times 10^{-9} \mathrm{M}\right)$ after 5 minutes $(\mathrm{a}), 24$ hours (b) and 48 hours (c) of incubation. See text for experimental conditions.

sensitivity to choline addition of $\mathrm{A} \beta \mathrm{P}$ channels incorporated into OxCh PLMs; indeed, choline does not modify some channel characteristics, such as voltage sensitivity, voltagedependence, and selectivity, but increases channel conductance, frequency, and stability, as indicated by the presence of two channel life-time components. 
In the Type I A $\beta$ P1-40 channel model proposed by Durell et al. [33], the amino acids able to form hydrogen bonds could be R5, D7, E11, K16, and D23. This has been invoked to explain the cation selectivity of the $\mathrm{A} \beta \mathrm{P} 1$ 40 channel. The $\mathrm{A} \beta \mathrm{P} 1-40$ channel incorporated in our membranes is anion selective. Choline does not modify the anion selectivity of $\mathrm{A} \beta \mathrm{P}$ channel incorporated in $\mathrm{OxCh}$ membrane, the aggregated configuration of $\mathrm{A} \beta \mathrm{P}$ peptide could be different, although this channel shows the same diameter, as reported in our previous paper [14], found in the theoretical calculation of the model proposed by Durell et al. [33].

Incorporation in POPC PLMs containing 33\% Ch seems to be driven by hydrophobic interaction, as the high hydrophobic amino acid content in the C-terminus of $\mathrm{A} \beta \mathrm{P} 1-$ 40 would suggest. Furthermore, our results seem to indicate that the $\mathrm{A} \beta \mathrm{P} 1-40$ channel is smaller than that formed in OxCh membranes, which could reflect a lower number of $\mathrm{A} \beta \mathrm{P} 1-40$ molecules assembled to form ion channels. However, it is worth noting that in POPC:Ch PLMs, the channel maintains its anionic selectivity, thus pushing the membrane into a hyperpolarized state.

Our CD results, obtained in an aqueous environment, indicate that choline does not modify $\mathrm{A} \beta \mathrm{P} 1-40$ peptide conformation but rather stabilizes it in a random coil conformation that is less prone to fibrillate. This result is consistent with the notion that the role played by choline is to counteract peptide aggregation, by maintaining it in the stabilized random coil form, so that in the membrane alpha-helices will arise in the peptide that tend to pack together to form ion channel rather than remain dispersed. Hydrogen bonds and ion pairs can be used to drive the association of local regions in the helices [34]. It is interesting to note that Kar et al. [9] found a concentration-dependent inhibition of high-affinity choline uptake by $\mathrm{A} \beta \mathrm{P}$ in rat hippocampal slides, indicating a direct interaction between $\mathrm{A} \beta \mathrm{P}$ and choline. $\mathrm{A} \beta \mathrm{P} 1-40$ present on the extracellular side of PC12 cells as a monomer has been found to increase the conductance of choline trapped inside cells. The authors [35] suggest that $\mathrm{A} \beta \mathrm{P} 1-40$ peptide acts as a choline carrier or that it modifies an endogenous ion channel or transporter. However, a suggestive possibility could be that choline crosses the A $\beta \mathrm{P} 1-40$ channel. To verify this possibility, permeability experiments on OxCh PLMs have been carried out. In our experimental conditions, where there are no other cellular components except for the $\mathrm{A} \beta \mathrm{P} 1-40$ channel, choline does not cross the $\mathrm{A} \beta \mathrm{P} 1-40$ channel.

Study of the effects of ACh on A $\beta$ P1-40 by means of $\mathrm{CD}$ indicates that $\mathrm{ACh}$ has no effect on peptides in solution; moreover, single channel conductance decreases when ACh is added on the cis side when the channel is open; on the other hand, in the same experimental conditions, ACh addition on the trans side did not modify channel conductance [36]. This indicates a specific effect of choline on $\mathrm{A} \beta \mathrm{P} 1-40$.

\section{Conclusions}

Our present findings support and extend the emerging concept that cholesterol can easily incorporate $A \beta P 1-40$, thus favouring its clearance; therefore, by removing the peptide from the environment, fibrillation will be avoided. Furthermore, the anionic nature of the A $\beta$ P1-40 channel formed in cholesterol-containing PLMs could be protective for the cells. Choline specifically accelerates this process. The greater effect of choline on depolarized membrane states found in this work could be of relevance for synaptic activity in that the higher ionic conductance, frequency and lifetime, as well as the anionic selectivity, all contribute to returning the membrane potential to basal condition. This could exert a kind of modulation on the synapses.

It may be speculated that owing to the high choline permeability found across the OxCh membrane, and the in vivo facilitated/active choline transport, ACh synthesis takes place quickly. The increase in ACh delivery and/or ACh esterase modulation may be beneficial to synaptic activity. Obviously, these aspects are merely speculative because we do not have any evidence that this occurs in vivo.

\section{Acknowledgments}

The authors would like to thank Professor Delia Picone for numerous discussions, suggestions, and criticisms on CD spectroscopy, and their colleague Anthony Green for proofreading and providing linguistic advice. This research was supported by a grant from the University of Bari.

\section{References}

[1] E. Masliah, M. Mallory, L. Hansen, R. DeTeresa, M. Alford, and R. Terry, "Synaptic and neuritic alterations during the progression of Alzheimer's disease," Neuroscience Letters, vol. 174, no. 1, pp. 67-72, 1994.

[2] S. W. Scheff, S. T. DeKosky, and D. A. Price, "Quantitative assessment of cortical synaptic density in Alzheimer's disease," Neurobiology of Aging, vol. 11, no. 1, pp. 29-37, 1990.

[3] S. T. DeKosky, S. W. Scheff, and S. D. Styren, "Structural correlates of cognition in dementia: quantification and assessment of synapse change," Neurodegeneration, vol. 5, no. 4, pp. 417421, 1996.

[4] S. W. Scheff and D. A. Price, "Synaptic pathology in Alzheimer's disease: a review of ultrastructural studies," Neurobiology of Aging, vol. 24, no. 8, pp. 1029-1046, 2003.

[5] R. D. Terry, E. Masliah, D. P. Salmon et al., "Physical basis of cognitive alterations in Alzheimer's disease: synapse loss is the major correlate of cognitive impairment," Annals of Neurology, vol. 30, no. 4, pp. 572-580, 1991.

[6] E. Masliah, "Mechanisms of synaptic dysfunction in Alzheimer's disease," Histology and Histopathology, vol. 10, no. 2, pp. 509-519, 1995.

[7] D. J. Selkoe, “Alzheimer's disease: genes, proteins, and therapy," Physiological Reviews, vol. 81, no. 2, pp. 741-766, 2001.

[8] P. Coleman, H. Federoff, and R. Kurlan, "A focus on the synapse for neuroprotection in Alzheimer disease and other dementias," Neurology, vol. 63, no. 7, pp. 1155-1162, 2004.

[9] S. Kar, A. M. Issa, D. Seto, D. S. Auld, B. Collier, and R. Quirion, "Amyloid $\beta$-peptide inhibits high-affinity choline uptake and acetylcholine release in rat hippocampal slices," Journal of Neurochemistry, vol. 70, no. 5, pp. 2179-2187, 1998. 
[10] D. D. Allen, Z. Galdzicki, S. K. Brining, R. Fukuyama, S. I. Rapoport, and Q. R. Smith, "Beta-amyloid induced increase in choline flux across PC12 cell membranes," Neuroscience Letters, vol. 234, no. 1, pp. 71-73, 1997.

[11] S. R. Ji, YI. Wu, and S. F. Sui, "Cholesterol is an important factor affecting the membrane insertion of $\beta$-amyloid peptide (A $\beta 1-40)$, which may potentially inhibit the fibril formation," Journal of Biological Chemistry, vol. 277, no. 8, pp. 6273-6279, 2002.

[12] N. Arispe, E. Rojas, and H. B. Pollard, "Alzheimer disease amyloid $\beta$ protein forms calcium channels in bilayer membranes: blockade by tromethamine and aluminum," Proceedings of the National Academy of Sciences of the United States of America, vol. 90, no. 2, pp. 567-571, 1993.

[13] R. Capone, F. G. Quiroz, P. Prangkio et al., "Amyloid- $\beta$ induced ion flux in artificial lipid bilayers and neuronal cells: resolving a controversy," Neurotoxicity Research, vol. 16, no. 1, pp. 1-13, 2009.

[14] S. Micelli, D. Meleleo, V. Picciarelli, and E. Gallucci, "Effect of sterols on beta-amyloid peptide (AbetaP 1-40) channel formation and their properties in planar lipid membranes," Biophysical Journal, vol. 86, no. 4, pp. 2231-2237, 2004.

[15] J. A. Hardy and G. A. Higgins, "Alzheimer's disease: the amyloid cascade hypothesis," Science, vol. 256, no. 5054, pp. 184-185, 1992.

[16] L. P. Choo-Smith, W. Garzon-Rodriguez, C. G. Glabe, and W. K. Surewicz, "Acceleration of amyloid fibril formation by specific binding of $\mathrm{A} \beta$-(1-40) peptide to ganglioside-containing membrane vesicles," Journal of Biological Chemistry, vol. 272, no. 37, pp. 22987-22990, 1997.

[17] J. L. Galbete, T. Rodriguez-Martin, E. Peressini, P. Modena, R. Bianchi, and G. Forloni, "Cholesterol decreases secretion of the secreted form of amyloid precursor protein by interfering with glycosylation in the protein secretory pathway," Biochemical Journal, vol. 348, no. 2, pp. 307-313, 2000.

[18] T. Tien, S. Carbone, and E. Dawidowicz, "Procedure for preparation of oxidized cholesterol membrane solution," Nature, vol. 212, no. 7, pp. 718-719, 1966.

[19] M. H. Tran, K. Yamada, and T. Nabeshima, "Amyloid $\beta$ peptide induces cholinergic dysfunction and cognitive deficits: a minireview," Peptides, vol. 23, no. 7, pp. 1271-1283, 2002.

[20] J. Winkler, L. J. Thal, F. H. Gage, and L. J. Fisher, "Cholinergic strategies for Alzheimer's disease," Journal of Molecular Medicine, vol. 76, no. 8, pp. 555-567, 1998.

[21] V. Parikh and M. Sarter, "Cortical choline transporter function measured in vivo using choline-sensitive microelectrodes: clearance of endogenous and exogenous choline and effects of removal of cholinergic terminals," Journal of Neurochemistry, vol. 97, no. 2, pp. 488-503, 2006.

[22] H. Freitag, W. Neupert, and R. Benz, "Purification and characterisation of a pore protein of the outer mitochondrial membrane from Neurospora crassa," European Journal of Biochemistry, vol. 123, no. 3, pp. 629-636, 1982.

[23] S. Micelli, E. Gallucci, D. Meleleo, V. Stipani, and V. Picciarelli, "Mitochondrial porin incorporation into black lipid membranes: ionic and gating contribution to the total current," Bioelectrochemistry, vol. 57, no. 2, pp. 97-106, 2002.

[24] E. Gallucci, D. Meleleo, S. Micelli, and V. Picciarelli, "Magainin 2 channel formation in planar lipid membranes: the role of lipid polar groups and ergosterol," European Biophysics Journal, vol. 32, no. 1, pp. 22-32, 2003.
[25] K. Röper, D. Corbeil, and W. B. Huttner, "Retention of prominin in microvilli reveals distinct cholesterol-based lipid microdomains in the apical plasma membrane," Nature Cell Biology, vol. 2, no. 9, pp. 582-592, 2000.

[26] C. Thiele, M. J. Hannah, F. Fahrenholz, and W. B. Huttner, "Cholesterol binds to synaptophysin and is required for biogenesis of synaptic vesicles," Nature Cell Biology, vol. 2, no. 1, pp. 42-49, 2000.

[27] P. Liu, P. Y. Wang, P. Michaely, M. Zhu, and R. G. W. Anderson, "Presence of oxidized cholesterol in caveolae uncouples active platelet-derived growth factor receptors from tyrosine kinase substrates," Journal of Biological Chemistry, vol. 275, no. 41, pp. 31648-31654, 2000.

[28] L. Song, M. R. Hobaugh, C. Shustak, S. Cheley, H. Bayley, and J. E. Gouaux, "Structure of staphylococcal $\alpha$-hemolysin, a heptameric transmembrane pore," Science, vol. 274, no. 5294, pp. 1859-1866, 1996.

[29] G. Fernandez-Ballester, J. Castresana, A. M. Fernandez, J. L. R. Arrondo, J. A. Ferragut, and J. M. Gonzalez-Ros, "Role of cholesterol as a structural and functional effector of the nicotinic acetylcholine receptor," Biochemical Society Transactions, vol. 22, no. 3, pp. 776-780, 1994.

[30] B. Hasse, F. Bosse, and H. W. Müller, "Proteins of peripheral myelin are associated with glycosphingolipid/cholesterolenriched membranes," Journal of Neuroscience Research, vol. 69, no. 2, pp. 227-232, 2002.

[31] N. Sanghera and T. J. T. Pinheiro, "Binding of prion protein to lipid membranes and implications for prion conversion," Journal of Molecular Biology, vol. 315, no. 5, pp. 1241-1256, 2002.

[32] X. Luo, D. Sharma, H. Inouye et al., "Cytoplasmic domain of human myelin protein zero likely folded as $\beta$-structure in compact myelin," Biophysical Journal, vol. 92, no. 5, pp. 15851597, 2007.

[33] S. R. Durell, H. R. Guy, N. Arispe, E. Rojas, and H. B. Pollard, "Theoretical models of the ion channel structure of amyloid $\beta$-protein," Biophysical Journal, vol. 67, no. 6, pp. 2137-2145, 1994.

[34] C. M. Deber and S. C. Li, "Peptides in membranes: helicity and hydrophobicity," Biopolymers, vol. 37, no. 5, pp. 295-318, 1995.

[35] Z. Galdzicki, R. Fukuyama, K. C. Wadhwani, S. I. Rapoport, and G. Ehrenstein, " $\beta$-Amyloid increases choline conductance of PC12 cells: possible mechanism of toxicity in Alzheimer's disease," Brain Research, vol. 646, no. 2, pp. 332-336, 1994.

[36] E. Gallucci, D. Meleleo, and S. Micelli, "Acetylcholine modulates the AbetaP1-40 single channel reconstituted in oxidized cholesterol PLM," in Proceedings of the 58th National Congress of the Italian Physiological Society, Blackwel, Lecce, Italy, 2007. 


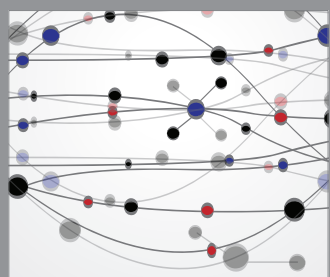

The Scientific World Journal
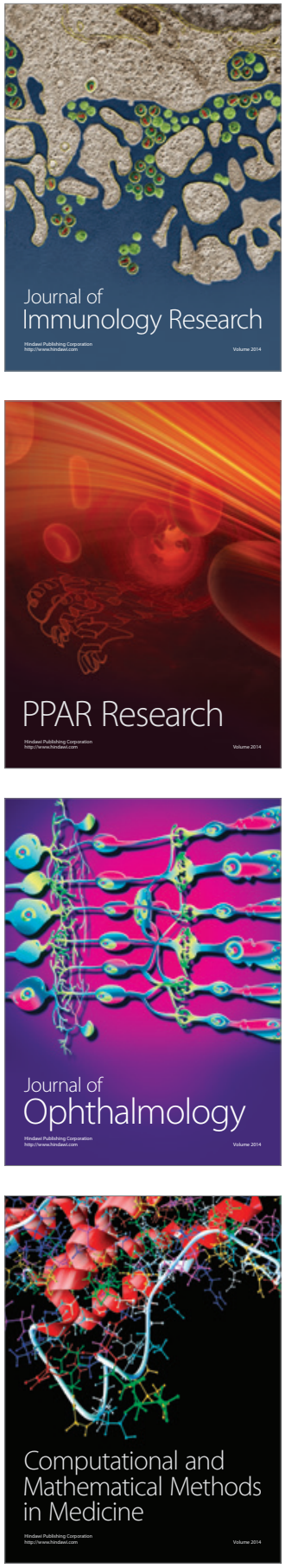

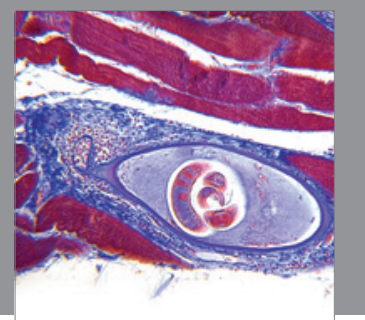

Gastroenterology

Research and Practice
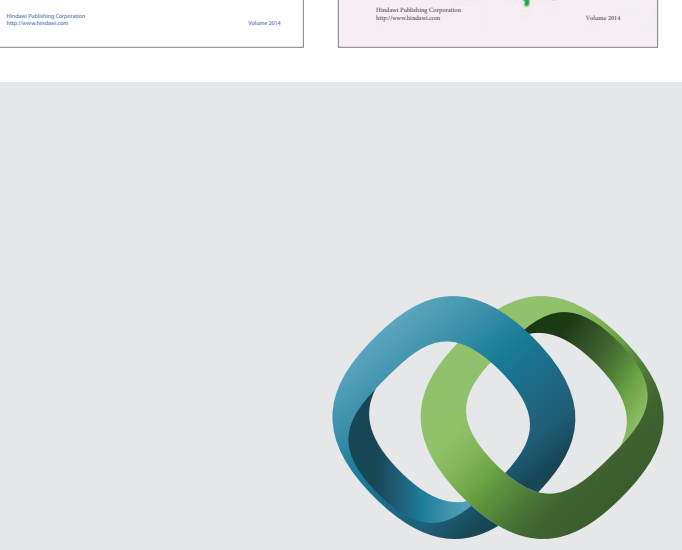

\section{Hindawi}

Submit your manuscripts at

http://www.hindawi.com
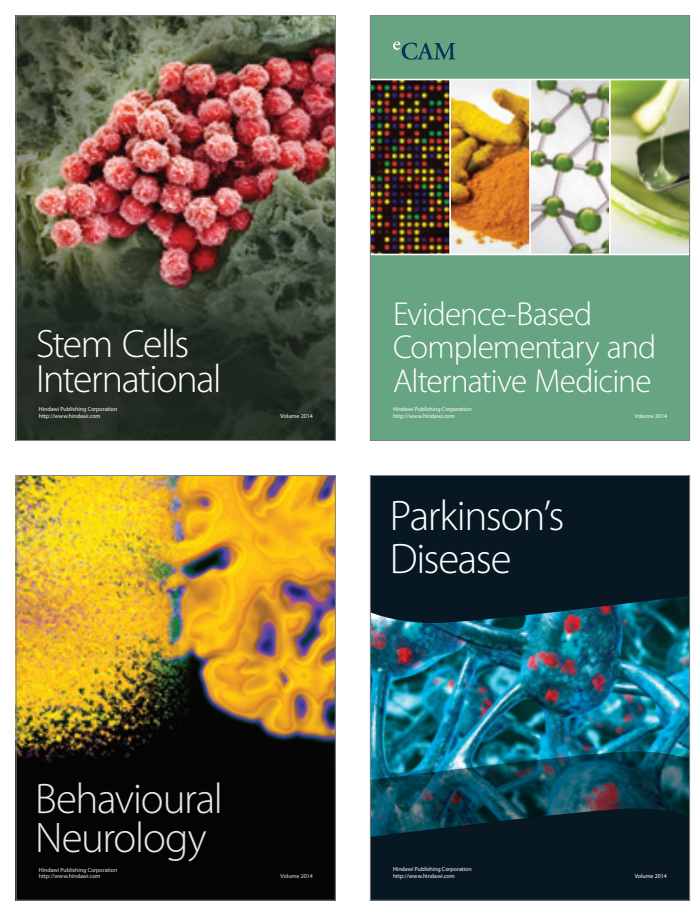

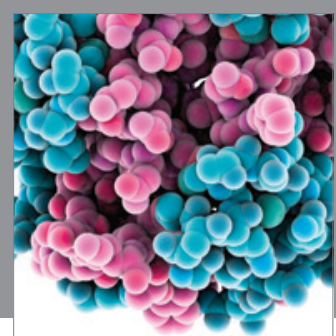

Journal of
Diabetes Research

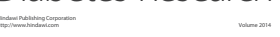

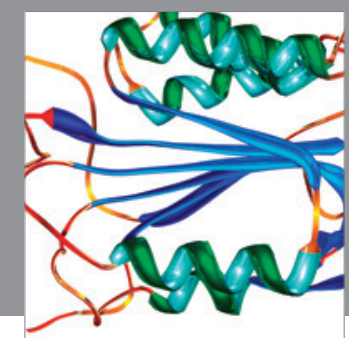

Disease Markers
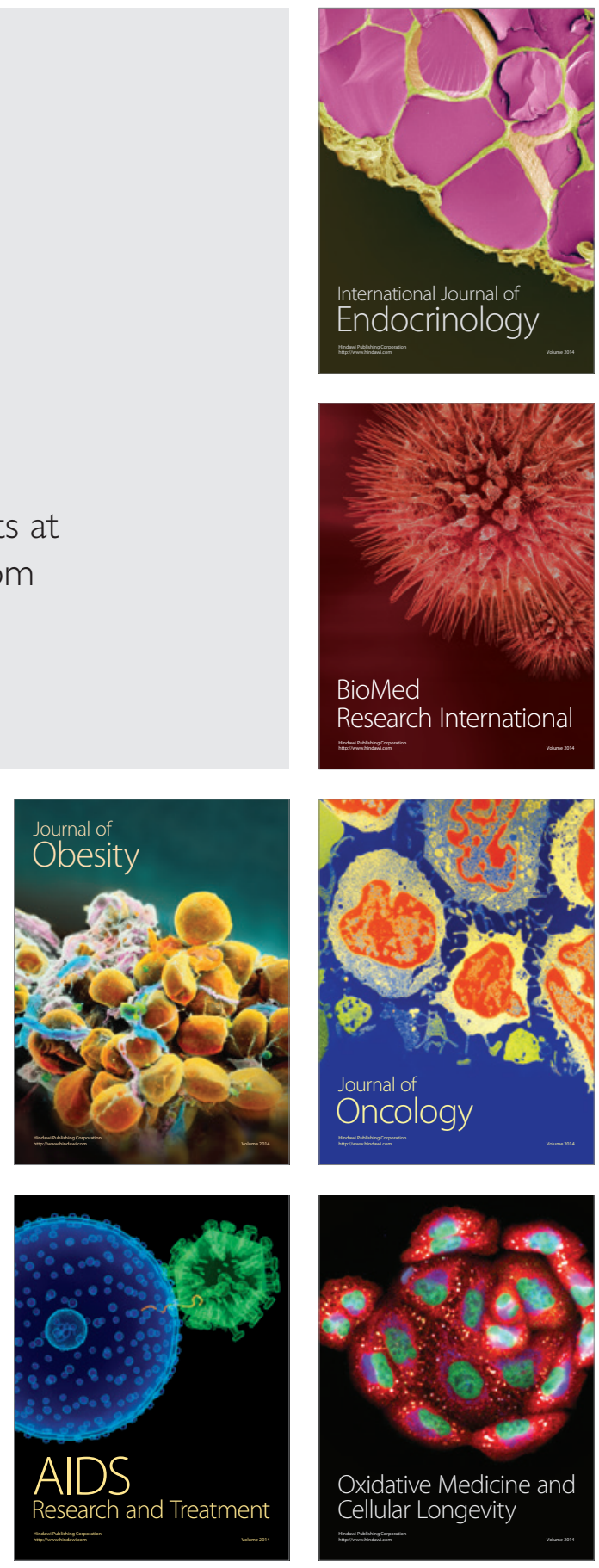